\title{
IMPLEMENTASI NILAI PENDIDIKAN MULTIKULTURAL DI SD NEGERI SANGIANG PULAU KABUPATEN BIMA
}

\author{
Hermanto $^{1}$, Arita Marini ${ }^{2}$, Arifin Maksum ${ }^{3}$ \\ alamat.pbmanto92@gmail.com ${ }^{1,}$ aritamarini@unj.ac.id ${ }^{2,}$ amaksum@unj.ac.id ${ }^{3}$ \\ Program Studi Doktor Pendidikan Dasar Pascasarjana Universitas Negeri Jakarta ${ }^{1}$ \\ Program Pascasarjana Universitas Negeri Jakarta ${ }^{2}$ \\ Program Pascasarjana Universitas Negeri Jakarta ${ }^{3}$
}

\begin{abstract}
Abstrak: Penelitian ini bertujuan untuk mendeskripsikan yaitu; 1). Peran kepala sekolah dalam implementasi nilai pendidikan multikultural di sekolah, 2). Peran guru dalam mengimplementasikan nilai pendidikan multikultural di sekolah, 3). Pentingnya pendidikan multikultural bagi peserta didik di SD Negeri Sangiang Pulau. Metode penelitian yang digunakan adalah metode kualitatif deskriptif dengan sumber data diperoleh dari kepala sekolah, guru dan siswa. Analisis data yang digunakan yaitu pengumpulan data, reduksi data, penyajian data, dan penarikan kesimpulan/ferivikasi. Teknik pengumpulan data yaitu observasi, wawancara, dan dokumentasi hingga triangulasi. Hasil dari penelitian ini adalah implementasi nilai pendidikan multikultural dapat dilakukan melalui kegiatan intrakurikuler disekolah dapat dilakukan dengan penguatan materi tentang keberagaman yaitu tentang beragam suku, budaya, agama dan adat istiadat. Sementara dalam kegiatan ekstrakurikuler dapat dilakukan dengan kegiatan kemah kebudyaan, karnaval pakaian adat istiadat tiap-tiap daerh yang ada di indonesia dan pendalaman mengenai bhineka tunggal ika dan pancasila
\end{abstract}

Kata kunci: Pendidikan Multikultural, Nilai Multikultural, Sekolah Dasar,.

\section{THE IMPLEMENTATION OF MULTICULTURAL EDUCATION VALUES IN SD NEGERI SANGIANG PULAU BIMA DISTRICT}

\begin{abstract}
This study aims to describe, namely; 1). The role of the principal in implementing the value of multicultural education in schools, 2). The role of teachers in implementing the value of multicultural education in schools, 3). The importance of multicultural education for students at SD Negeri Sangiang Pulau. The research method used in this research is descriptive qualitative method with data sources obtained from the principal, teachers and students. Data analysis used is data collection, data reduction, data presentation, and drawing conclusions. Data collection techniques are observation, interviews, and documentation to triangulation. The result of this research is that the implementation of multicultural education values can be done through intracurricular activities in schools by strengthening material about diversity, namely about various ethnicities, cultures, religions and customs. Meanwhile, extracurricular activities can be
\end{abstract}


Hermanto, Arita, Arifin. Implementasi Nilai Pendidikan Multikultural carried out with cultural camp activities, carnival of traditional clothing for each region in Indonesia and an in-depth study of the diversity of ika and Pancasila.

Keywords: Multicultural Education, Multicultural Values, Elementary School.

\section{PENDAHULUAN}

Kehidupan masyarakat Indonesia penuh dengan keberagaman baik keberagaman budaya, suku, bangsa, agama dan kepercayaan. Indonesia merupakan negara yang majemuk (Baldah, 2016). Berbagai persoalan di masyarakat terkait dengan isu perbedaan, seperti perbedaan antar kelompok, kekerasan antar kelompok, tawuran antar pelajar, bullying pada anak sekolah dengan sesama temannya, menunjukan betapa rentannya rasa kebersamaan dalam keberagaman yang telah dibangun oleh para pendiri bangsa. Probkematika ini memunculkan adanya diskriminasi diantara sesama. Persoalan ini tidak bisa dibiarkan terjadi scara terus menerus, apalagi dikalangan anak sekolah dasar yang masih membutuhkan penguatan mental dan karakternya. Oleh karena pendidikan merupakan media yang sangat tepat untuk mengenalkan nilai-nilai multikultural (Wahyudin, 2017).

Berdasarkan pasal 4 ayat 1 Undang-Undang Nomor 20 tahun 2003, Permendikbud (2016) maka pengakuan atas perbedaan individual dan latar belakang budaya peserta didik perlu mendapatkan perhatian serius. Langkah strategisnya, yakni melalui pendidikan multikultural di sekolah. Pendidikan multikultural merupakan suatu rangkaian kepercayaan dan penjelasan yang mengakui dan menilai pentingnya keragaman budaya, dan etnis di dalam membentuk budaya hidup, pengalaman sosial, identitas pribadi, kesempatan pendidikan dari individu, kelompok maupun negara.

Desmita (2016) menjelaskan bahwa anak usia sekolah dasar 7 sampai 11 tahun berada pada tahap mythic literal faith. Tahap perkembangan kognitifnya, berada pada perkembangan operasional konkret yakni memikitkan segala sesuatunya secara konkret, anak secara sistematis mulai mengambil makna dari tradisi masyarakatnya. Oleh karena itu guru harus memahami karakteristik perkembangan dan keberagaman peserta didik di sekolah, agar pembelajaran dapat ditingkatkan dan bermakna.

Pendidiksn multikultural menurut Zamroni (2011) suatu bentuk reformasi pendidikan yang bertujuan untuk memberikan kesempatan yang setara kepada siswa tanpa memandang latar belakangnya, sehingga semua siswa dapat meningkatkan 
Hermanto, Arita, Arifin. Implementasi Nilai Pendidikan Multikultural kemampuan yang secara optimal dengan ketertarikan, minat dan bakat yang dimiliki. Hanum (2009) menyatakan tujuan utama pendidikan multikultural mengubah pendekatan pembelajatan kearah memberi peluang yang sama pada setiap peserta didik, yakni: 1). Tidak ada yang dikorbankan demi persatuan; 2). Siswa ditanamkan pemikiran lateral, keanekaragaman; 3). Keunikan itu juga dihargai. Hal ini berarti harus ada perubahan sikap, perilaku, dan nilai-nilai khususnya civitas akademika sekolah. Penekanan pemdidikan multikultural lebih difokuskan pada pendidikannya. Siswa seharusnya dilatih dan dibiasakan untuk memahami semua jenis pengetahuan, aktif mendiskusikan konstruksi pengetahuan dan interpretasi.

Disadari atau tidak siswa sekolah dasar saat ini telah memasuki zona budaya maya bahkan menjadi aktor sekaligus korban dalam wilayah geografi mental tersebut. Tidak lagi menjadi hal baru dan mengherankan bahwa anak-anak sekolah dasar di kota bima khususnya di desa sangiang mempunyai akun pribadi seperti facebook, instagram, whatsaap, dan telegram sehingga kapan saja dapat meng-update statusnya, merekayasa gambar, berita, dan memposting ke wilayah publik. Siswa sekolah dasar sudah mampu mendeskripsikan dirinya dengan bebas dengan siapa pun, merasa ok, hebat, terkenal dan berlomba mengumpulkan teman sebanyak-banyaknya di media sosial. Wilayah sosial siswa tidak lagi dibatasi tembok rumah dan halaman sekolah tetapi diukur oleh kemampuan dan waktu mereka berkutat menjagkau siapapun dan apapun dengan teknologi informasi (Dike, 2017).

Penelitian mengenai pelaksanaan pendidikan multikultural telah dilakukan oleh beberapa peneliti antara lain oleh Lincoln (2011), Sudrajat (2014), dan Najmina (2018). Riset Lincoln (2011) menunjukan kesetaraan pendidikan selalu relatif dan pada proses menuju tingkat yang lebih tinggi baik secara kuantitas dan kualitas tergantung pada sejarah dan sosial tertentu; pemerataan pendidikan adalah cita-cita yang sulit dijangkau karena varietas masing-masing siswa, dalam hal latar belakang bahasa dan budaya, tingkat kognitif, kemamouan, dan gaya belajar, dan keterbatasan pengetahuan, keterampilan dan profesionalisme guru.

Sementara penelitian Sudrajat (2014) menunjukan melalui sekolah, guru dapat menanamkan hakikat dan praktik pluralisme bagi peserta didik, guru perlu bertindak secara kreatif dalam menjembatani pluralitas menuju budaya yang plural dan damai, sebagai ujung tombak pendidikan multikultural, guru harus mempunyai pemahaman 
Hermanto, Arita, Arifin. Implementasi Nilai Pendidikan Multikultural yang memadai tentan multikulturalisme dan pendidikan multikultural. Dalam kegiatan pembelajaran, guru mengembangkan iklim yang multiculture oriented yang mengedepankan keadilan sosial dan budaya bagi siswa, sehingga guru perlu melakukan transformasi diri menuju pribadi yang multikultur dan mempunyai desain pembelajaran yang berbasis multikultur yang tidak berorientasi pada kognitif semata.

Kemudian penelitian Najmina (2018) menunjukan pendidikan multikulturalisme harus diterapkan dalam proses pembelajaran melalui proses pembiasaan, pembelajaran multikultural dilakukan dengan pembentukan pola pikir, sikap, tindakan, dan pembiasaan sehingga muncul kesadaran nasional keIndonesiaan. Karakter keindonesiaan tersebut meliputi: kesadaran kebanggaan sebagai bangsa, kemandirian dan keberanian sebagai bangsa, kesadaran kehormatan sebagai bangsa, kesadaran melawan penjajahan, kesadaran berkorban demi bangsa, keasadaran nasionalisme bangsa lain, dan kesadaran kedaerahan menuju kebangsaan. Terwujudnya karakter keindonesiaan tersebut menjadi landasan kuat sebagai ciri khas manusia Indonesia yang kuat

Tujuan penelitian pada artikel ini adalah untuk mendeskripsikan dan menganalsisis implementasi nilai-nilai pendidikan multikultural di SD Negeri Sangiang Pulau, Kabupaten Bima Nusa Tenggara Barat. Secara rinci yaitu: 1). Mendeskripsikan peran kepala sekolah dalam implementasi nilai pendidikan multikultual di sekolah, 2). Mendeskripsikan peran guru dalam mengimplementasikan nilai pendidikan multikultural di sekolah, dan 3). Mendeskripsikan pentingnya pendidkan multikultural bagi peserta didik sekolah dasar.

\section{METODE}

Penelitian ini menggunakan pendekatan kualitatif dengan metode deskriptif. Penelitian kualitatif dengan metode deskriptif adalah metode yang menjelaskan atau mendeskripsikan suatu fakta, data, dan objek penelitian secara sistematis dan sesuai dengan situasi alamiah. Terkait hal yang diteliti, hasil penelitian lebih menekankan pada makna dari pada hasil, dan hasil penelitian tidak mengikat serta dapat berubah sesuai dengan kondisi yang dihadapi di lapangan penelitian dan diinterpretasikan dan dituliskan dalam bentuk kata-kata atau deskriptif berdasarkan fakta di lapangan (Anggito \& Setiawan, 2018). 
Hermanto, Arita, Arifin. Implementasi Nilai Pendidikan Multikultural

Penelitian ini dilaksanakan di SDN Pulau Sangiang, Kecamatan Wera,

Kabupaten Bima, Nusa Tenggara Barat dengan sumber data penelitian yaitu informan

(Kepala Sekolah, Guru, dan Peserta didik). Peneliti berperan sebagai human instrument (peneliti melakukan penelitiannya sendiri). Teknik pengumpulan data menggunakan wawancara, observasi, dan dokumentasi (Moleong, 2017). Analisis data bersifat kualitatif, dengan menggunakan model Milles \& Huberman yaitu Reduksi data, Penyajian data dan kesimpulan atau Verifikasi (Miles \& Huberman, 2013). Dan adapun teknik pemeriksaan keabsahan data yang digunakan adalah: triangulasi data, meningkatkan ketekunan, dan menggunakan bahan referensi (Sugiyono, 2018).

\section{HASIL}

Pada bagian ini akan jelaskan hasil penelitian berdasarkan hasil wawancara dan obeservasi yang dilakukan oleh peneliti tentang 1) Peran kepala sekolah dalam mengimplementasikan nilai Pendidikan multikultural, 2) Peran guru dalam mengimplementasikan nilai Pendidikan multikultural, dan 3) Pentingnya pendidikan multikultural bagi peserta didik, sebagai berikut:

\section{Tabel 4.1. Hasil Observasi}

\begin{tabular}{|c|c|c|}
\hline Aspek yang diamati & Deskripsi aspek yang diamati & Kesimpulan \\
\hline $\begin{array}{l}\text { Peran kepala sekolah } \\
\text { dalam implementasi } \\
\text { nilai pendidikan } \\
\text { multikuktural }\end{array}$ & $\begin{array}{l}\text { Kamis } 29 \text { oktober } 2020 \\
\text { Kepala sekolah dalam menerapkan nilai Pendidikan } \\
\text { multicultural di sekolah yaitu pertama menguatkan } \\
\text { kompetensi guru senior dan yunior agar benar-benar } \\
\text { profesional dalam menjalankan tugas sebagai guru } \\
\text { sehingga dalam mengajarkan siswa tepat sasaran. } \\
\text { Jumat, } 30 \text { Oktober } 2020 \\
\text { Dikatakan bahwa kepala sekolah akan melakukan } \\
\text { supervisi pembelajaran dengan sasaran RPP dan } \\
\text { proses pembelajaran serta mengaktifkan guru dalam } \\
\text { kelompok kerja guru (KKG) dengan menyusun } \\
\text { jadwal KKG. } \\
\text { Jumat, } 30 \text { Oktober } 2020 \\
\text { Lebih lanjut dikatakan bahwa upaya ini dilakukan } \\
\text { untuk memotivasi para guru yang masih belum linier } \\
\text { agar segera melanjutkan studinya misalnya dari S1 } \\
\text { PGSD ke S2 PGSD atau dari D3 PGSD ke S1 PGSD } \\
\text { hal ini saya lakukan untuk meningkatkan kapasitas } \\
\text { guru di sekolah yang saya pimpin yang nantnya akan } \\
\text { dapat mengimpelmentasikan nilai-nilai pendidikan } \\
\text { multikultural pada peserta didik. }\end{array}$ & $\begin{array}{l}\text { Kepala sekolah dalam } \\
\text { mengimplementasi } \\
\text { nilai Pendidikan } \\
\text { multicultural pada } \\
\text { peserta didik di SD } \\
\text { yaitu: 1) Menguatkan } \\
\text { kompetensi guru senior } \\
\text { dan yunior, 2) } \\
\text { membina guru agar } \\
\text { dapat melakukan } \\
\text { supervise pembelajaran } \\
\text { dengan sasaran RPP, } \\
\text { ke 3) memotivasi para } \\
\text { guru agar bisa } \\
\text { melanjutkan studi liner } \\
\text { baik D3, S1, dan S2. }\end{array}$ \\
\hline $\begin{array}{l}\text { Peran guru dalam } \\
\text { mengimplementasika }\end{array}$ & $\frac{\text { Kamis } 30 \text { oktober } 2020}{\text { Pada intinya peran guru dalam implementasi nilai }}$ & $\begin{array}{l}\text { Guru dalam } \\
\text { mengimplementasi }\end{array}$ \\
\hline
\end{tabular}


Hermanto, Arita, Arifin. Implementasi Nilai Pendidikan Multikultural

\begin{tabular}{|c|c|c|}
\hline $\begin{array}{l}\text { n nilai pendidikan } \\
\text { multikultural }\end{array}$ & $\begin{array}{l}\text { pendidikan multikultural di sekolah yaitu: dengan } \\
\text { melalui kegiatan intrakurikuler dan ekstrakulikuler. } \\
\text { Dalam kegiatan intrakurikuler misalnya guru selalu } \\
\text { memberikan pengajaran dan pemahaman kepada } \\
\text { peserta didik petingnya menjaga keberagaman dan } \\
\text { guru melakukan itu melalui penguatan materi } \\
\text { keberagaman di kelas. } \\
\text { Sabtu, } 31 \text { Oktober } 2020 \\
\text { Guru pada diskusi siswa di kelas tetap utamakan } \\
\text { komunikasi } 2 \text { arah yang humanis seperti layaknya } \\
\text { seorang anak dan orang tuanya. } \\
\text { Senin, } 2 \text { November } 2020 \\
\text { Yang dilakuan oleh guru adalah guru sebagai } \\
\text { fasilitator yang berusaha memahami keunikan tiap } \\
\text { individu atau siswa di kelas. } \\
\text { Selasa, } 3 \text { November } 2020 \\
\text { pada kegiatan ektrakurikuler yang lakukan adalah } \\
\text { kegiatan kemah kebudyaan, karnaval pakaian adat } \\
\text { istiadat tiap-tiap daerah yang ada di indonesia serta } \\
\text { pendalaman nilai tentang bhineka tunggal ika dan } \\
\text { pancasila. }\end{array}$ & $\begin{array}{l}\text { nilai pendidikan } \\
\text { multikultural } \\
\text { sekolah yaitu: melalui } \\
\text { kegiatan intrakurikuler } \\
\text { dan ekstrakulikuler. } \\
\text { kegiatan intrakurikuler } \\
\text { misalnya guru selalu } \\
\text { memberikan } \\
\text { pemahaman kepada } \\
\text { peserta didik didik } \\
\text { kelas. } \\
\text { Kegiatan ektrakurikuler } \\
\text { adalah kemah budya, } \\
\text { karnaval pakaian adat } \\
\text { istiadat tiap-tiap daerah } \\
\text { yang ada di indonesia } \\
\text { serta pendalaman nilai } \\
\text { tentang bhaneka } \\
\text { tunggal ika dan } \\
\text { pancasila. }\end{array}$ \\
\hline $\begin{array}{l}\text { Pentingnya } \\
\text { pendidikan } \\
\text { multicultural bagi } \\
\text { peserta didik }\end{array}$ & $\begin{array}{l}\text { Rabu, } 4 \text { November } 2020 \\
\text { Adapun pentingnya pendidikan multikultural bagi } \\
\text { peserta didik yaitu sebagai sarana alternatif } \\
\text { pemecahan konflik, peserta didik diharapkan tidak } \\
\text { meninggalkan akar budayanya, dan pendidikan } \\
\text { multikultural sangat relevan digunakan untuk } \\
\text { demokrasi yang ada seperti sekarang ini. } \\
\text { Kamis, } 5 \text { November } 2020 \\
\text { Penting pendidikan multikultural dilakasanakan } \\
\text { disekolah dasar agar peserta didik dapat memahami } \\
\text { tentang keberagaman dan cara menghargai satu sama } \\
\text { lain sebagai wujud nyata mencintai keberagaman } \\
\text { bangsa Indonesia yang majemuk ini. } \\
\text { Jumat, } 6 \text { November } 2020 \\
\text { Selain dari pada itu para peserta didik sejak dini } \\
\text { memahami perbedaan-perbedaan keragaman itu } \\
\text { sebagai karunia Tuhan Yang Maha Esa yang patut di } \\
\text { syukuri sehingga dalam implementasi nilai } \\
\text { multikulturalisme dalam kehidupan sehari-hari dapat } \\
\text { diinternalisasi dengan baik oleh peserta didik } \\
\text { sekolah dasar baik di sekolah, keluarga, dan } \\
\text { masyarakat. }\end{array}$ & $\begin{array}{lr}\text { Pentingnya pendidikan } \\
\text { multicultural bagi } \\
\text { peserta didik yaitu } \\
\text { sebagai sarana } \\
\text { alternatif pemecahan } \\
\text { konflik. Selain itu juga } \\
\text { Pendidikan } \\
\text { multikultural } \\
\text { dilakasanakan } \\
\text { disekolah dasar agar } \\
\text { peserta didik dapat } \\
\text { memahami tentang } \\
\text { keberagaman dan cara } \\
\text { menghargai satu sama } \\
\text { lain sebagai wujud } \\
\text { nyata mencintai } \\
\text { keberagaman bangsa } \\
\text { Indonesia yang } \\
\text { majemuk sejak dini. }\end{array}$ \\
\hline
\end{tabular}

Tabel 4.2 Hasil Wawancara

\begin{tabular}{|c|l|}
\hline Aspek Pertanyaan & \multicolumn{1}{|c|}{ Jawaban/Kesimpulan } \\
\hline $\begin{array}{c}\text { 1. Apa yang diketahui tentang } \\
\text { Pendidikan multicultural di } \\
\text { Sekolah menurut bapak } \\
\text { sebagai guru? }\end{array}$ & $\begin{array}{l}\text { Pendidikan multikultural yang saya ketahui yaitu pendidikan yang } \\
\text { berlandasakan pada asas dan prinsip multikulturalisme yakni } \\
\text { konsep keberagaman dengan menerima setiaap perbedaan yang } \\
\text { ada baik berupa perbedaan ras, agama, dan kelas sosial. Yang tidak } \\
\text { menimbulkan diskriminasi terhadap sesama. }\end{array}$ \\
\hline $\begin{array}{c}\text { 2. Bagaiaman Peran kepala } \\
\text { sekolah/guru dalam } \\
\text { menerapkan nilai pendidikan }\end{array}$ & $\begin{array}{l}\text { Peran kepala sekolah atau guru dalam implementasi nilai } \\
\text { pendidikan multicultural di sekolah dasar yaitu yaitu: melalui } \\
\text { kegiatan intrakurikuler dan ekstrakulikuler. Pada kegiatan }\end{array}$ \\
\hline
\end{tabular}


Hermanto, Arita, Arifin. Implementasi Nilai Pendidikan Multikultural

\begin{tabular}{|c|l|}
\hline \hline multicultural? & $\begin{array}{l}\text { intrakurikuler misalnya guru selalu memberikan pemahaman } \\
\text { kepada peserta didik didik kelas. Sementara Kegiatan } \\
\text { ektrakurikuler adalah kemah budya, karnaval pakaian adat istiadat } \\
\text { tiap-tiap daerah yang ada di indonesia serta pendalaman nilai } \\
\text { tentang bhineka tunggal ika dan pancasila. }\end{array}$ \\
\hline $\begin{array}{c}\text { 3. Seberapa Penting pendidikan } \\
\text { multicultural bagi peserta } \\
\text { didik di sekolah? }\end{array}$ & $\begin{array}{l}\text { Pentinya pendidikan multicultural bagi peserta didik adalah } \\
\text { sebagai suatu dasar yang menjadi modal peserta didik dalam } \\
\text { kehidupan lebih lanjut, karena Negara Indonesia memiliki berbagai } \\
\text { macam suku, budaya dan agama maka penanaman nilai multural } \\
\text { dalam Pendidikan dasar adalah suatu wujud nyata dari persiapan } \\
\text { kehidupan yang akan datang. Nilai-nilai yang akan ditanamkan } \\
\text { adalah mencintai keberagamaan, Nasionalisme, Karakter, } \\
\text { kejujuran dan kepribadian yang tanggung jawab. }\end{array}$ \\
\hline $\begin{array}{c}\text { 4. Apa saja kegiatan yang } \\
\text { dilakukan oleh peserta didik } \\
\text { sebagai wujud nyata } \\
\text { implementasi dari nilai } \\
\text { multicultural? }\end{array}$ & $\begin{array}{l}\text { Adapun kegiatan yang dilakukan oleh peserta didik dan sekolah } \\
\text { dalam mengimplementasi nilai Pendidikan multicultural adalah } \\
\text { kegiatan pameran keagamaan yang menghadirkan pakaian dan } \\
\text { bentuk agama yang ada di Indonesia, karnaval dengan memakai } \\
\text { baju adat Indonesia dari berbagai daerah. }\end{array}$ \\
\hline $\begin{array}{c}\text { 5. Adakah program khusus yang } \\
\text { dilakukan oleh sekolah dalam } \\
\text { menumbuhkan nilai }\end{array}$ & $\begin{array}{l}\text { Adapu program khusus yang dilakukan oleh sekolah adalah } \\
\text { dengan menanamkan nilai multikulturalisme pada papan Karakter } \\
\text { yang di temple di dinding, dan di muat juga dalam pembelajaran di } \\
\text { kelas dan diluar kelas. }\end{array}$ \\
mulyikultural pada peserta \\
didik?
\end{tabular}$\quad$\begin{tabular}{l}
\hline \\
\hline
\end{tabular}

\section{PEMBAHASAN}

Pelaksanaan pendidikan multikultural dalam kehidupan di SD Negeri Sangiang Pulau Kabupaten Bima. Dilakukan secara terpadu dengan melalui kegiatan intrakurikuler, dan kegiatan ekstrakurikuler. Kegiatan tersebut dilakukan dengan sangat beragam, dan disesuaikan dengan minat dan bakat peserta didik. Hal ini dilakukan agar peserta didik dapat mempraktikan secara langsung sesuai dengan dunia nyata. Kegiatan intrakurikuler disekolah dapat dilakukan dengan penguatan materi tentang keberagaman yaitu tentang beragam suku, budaya, agama dan adat istiadat. Sementara dalam kegiatan ekstrakurikuler dapat dilakukan dengan kegiatan kemah kebudyaan, karnaval pakaian adat istiadat tiap-tiap daerh yang ada di indonesia dan pendalaman mengenai bhineka tunggal ika dan pancasila.

Dalam proses implementasi pendidikan multukultural tersebut juga tidak terlepas dari peran penting dari kepala sekolah, guru, dan siswa. Karena itu proses implementasi nilai-nilai pendidikan multikultural dapat dijelaskan secara rinci berdasarkan peran kepala sekolah, guru, dan peserta didik. Hal tersebut dapat dijelaskan sebagai berikut: 
Hermanto, Arita, Arifin. Implementasi Nilai Pendidikan Multikultural

Peran Kepala Sekolah dalam Mengimplementasikan Nilai Pendidikan Multikultural

Berdasarkan hasil observasi dan wawancara dengan kepala sekolah melalui via telepon seluler pada hari kamis 29 oktober 2020 yang menyatakan "Saya dalam mengimplementasikan nilai pendidikan multikultural si sekolah yaitu pertama saya kuatkan kompetensi guru senior dan yunior agar benar-benar profesional dalam menjalankan tugas sebagai guru sehingga dalam mengajarkan siswa tepat sasaran. Lebih lanjt dia katakan, dan saya melakukan supervisi pembelajaran dengan sasaran RPP dan proses pembelajaran serta mengaktifkan guru dalam kelompok kerja guru (KKG) dengan menyusun jadwal KKG, saya pun memotivasi para guru yang masih belum linier agar segera melanjutkan studinya misalnya dari S1 PGSD ke S2 PGSD atau dari D3 PGSD ke S1 PGSD hal ini saya lakukan untuk meningkatkan kapasitas guru di sekolah yang saya pimpin yang nantnya akan dapat mengimpelmentasikan nilai-nilai pendidikan multikultural pada peserta didik, tutupnya" (W.KS.29.10.2020).

Peran kepala sekolah dalam mengimplementasikan pendidikan multikultural di sekolah yaitu: (1) menugaskan guru senior membina guru yunior untuk meningkatkan kompetensi guru terutama kompetensi profesional; (2) membina guru dengan melaksanakan supervisi pembelajaran dengan sasaran Rancangan Pelaksanaan Pembelajaran (RPP) dan proses pembelajaran di kelas; (3) mengaktifkan guru dalam kelompok kerja guru (KKG) dengan cara menyusun jadwal kegiatan KKG dan memantaunya setiap minggu sekali dan paling sedikit sebulan sekali dengan membahas tentang permasalahan pembelajaran; (4) kepala sekolah menugaskan guru mengikuti kegiatan seminar atau penataran berdasarkan materi dan minat guru dan memotivasi guru supaya melakukan studi lanjut untuk meningkatkan kualifikasi guru dari D2 PGSD ke S1 PGSD atau dari S1 PGSD ke S2 PGSD; (5) mengusulkan guru untuk mengikuti sertifikasi guru dan membina guru yang sudah lulus sertifikasi guru; (6) membimbing guru dalam melaksanakan penelitian tindakan kelas (PTK) mulai dari cara menyusun proposal penelitian, cara melaksanakan penelitian dan cara menyusun laporan hasil penelitian tindakan kelas.

\section{Peran Guru dalam Mengimplementasikan Nilai Pendidikan Multikultural}


Hermanto, Arita, Arifin. Implementasi Nilai Pendidikan Multikultural

Guru merupakan ujung tombak dalam mengimplementasikan nilai-nilai pendidikan multikultural di sekolah. Dalam usaha menentukan keberhasilan pemahaman lintas budaya peserta didik, cara mengajar, kepribadian guru, materi pembelajaran dapat mempengaruhi keberhasilan proses pembelajaran dalam mendukung pengembangan situasi dan kondisi yang kondusif di sekolah berdasarkan pada kehidupan mutltikultural bagi warga sekolah khususnya dan masyarakat sekitar pada umumnya (Gaharu, 2014).

Kegiatan pembelajaran pendidikan multikultural menurut Zubaidi (2004: 77) adalah guru dituntut mau dan mampu menerapkan strategi pembelajaran kooperatif harus menerapkan di antaranya: adanya saling ketergantungan, adanya interaksi tatap muka yang membangun, pertanggung jawaban secara individu, ketrampilan sosial dan efektivitas proses pembelajaran dalam kelompok. Sekolah yang mengelola pendidikan berdasarkan multikultural senantiasa menghormati, menghargai perbedaan yang ada pada warga sekolah dengan latar belakang nilai agama, suku, ras, bahasa, etnis dan golongan yang ada di sekolah, baik terhadap peserta didik, guru, karyawan, staf kependidikan maupun komite sekolah dan semua komponen yang berkepentingan dengan sekolah.

Berdasarkan hasil observasi dan wawancara dengan salah satu guru SD Negeri Sangiang Pulau melalui via telepon seluler pada hari Jumat 30 oktober 2020 yang menyatakan bahwa: "Pada intinya peran saya sebagai guru dalam implementasi nilai pendidikan multikultural di sekolah yaitu: dengan kegiatan intrakurikuler dan ekstrakulikuler. Dalam kegiatan intra misalnya saya selalu memberikan pemahaman kepada peserta didik petingnya menjaga keberagaman dan saya lakukan itu melalui penguatan materi keberagaman di kelas, pada diskusi siswa saya tetap utamakan komunikasi 2 arah yang humanis seperti layaknya seorang seorang anak dan orang tuanya. Selanjutnya peran yang saya lakukan adalah sebagai fasilitator yang berusaha memahami keunikan tiap individu di kelas dan selanjutnya pada kegiatan ektrakurikuler yang saya lakukan adalah kegiatan kemah kebudyaan, karnaval pakaian adat istiadat tiap-tiap daerah yang ada di indonesia serta pendalaman nilai tentang bhineka tunggal ika dan pancasila" (W.G.30.10.2020).

Guru memperhatikan anak secara personal dan menjalin hubungan yang humanis bukan otoriter. Melalui komunikasi 2 arah, terjalin relasi seperti layaknya 
Hermanto, Arita, Arifin. Implementasi Nilai Pendidikan Multikultural teman. Guru selalu mengutamakan komunikasi, diskusi dan kesepakatan kepada anakanak. Komunikasi dan kesepakatan dilakukan kepada semua anak termasuk anak berkebutuhan khusus. Melalui diskusi, perbedaan diolah menjadi hal yang wajar. Setiap diskusi menghasilkan kesepakatan bersama. Melalui kesepakatan bersama guru menerapkan nilai-nilai universal kemanusiaan Kemudian, peran guru dalam menerapkan pendidikan multikultural di kelas yaitu guru berperan sebagai fasilitator, guru berperan memahami keunikan individu dan guru berperan membangun hubungan yang humanis kepada setiap anak, orangtua dan masyarakat. Peran tersebut, sejalan dengan konsep pendidikan multikultural yang dibangun oleh SD Negeri Sangiang Pulau: Menerapkan keadilan sosial melalui memberi kesempatan setiap anak untuk mengalami proses belajar. Anak berkebutuhan khusus juga memiliki kesempatan belajar di SD Negeri Sangiang Pulau. Menerapkan kemanusiaan melalui memberikan ruang kepercayaan kepada anak, dialog, kesepakatan dan tidak menjauhkan anak dari lingkungannya. Dan dalam kegiatan ektrakurikuler guru melakukan kegiatan kemah kebudyaan, karnaval pakaian adat istiadat tiap-tiap daerah yang ada di indonesia serta pendalaman nilai tentang bhineka tunggal ika dan pancasila, ini dilakukan untuk mendorong kesadaran peserta didik tentang pentingnya menjaga keberagaman.

\section{Pentingnya Pendidikan Multikultural bagi Peserta Didik}

Penanaman nilai-nilai melalui sistem pendidikan saat ini telah mengalami penurunan, di samping materi tentang budi pekerti yang berorientasi pada unsur homogenisasi tidak menghasilkan sebagaimana yang diharapkan. Untuk itu, peran pendidikan multikutural perlu diterapkan melalui pendidikan dasar sampai pendidikan tinggi, karena melalui penerapan pendidikan multikultural dapat membantu siswa mengerti, menerima, dan menghargai orang dari suku, budaya dan nilai yang berbeda (Praptini, 2017).

Puspita (2018) menyatakan pendidikan multikultural adalah pendidikan yang berlandaskan pada asas dan prinsip konsep multikulturalisme yakni konsep keberagaman yang mengakui,menerima dan menegaskan perbedaan dan persamaan manusia yang dikaitkan dengan gender, ras, dan kelas, agama berdasarkan nilai dan paham demokratis yang membangun pluralisme budaya dalam usaha memerangi prasangka dan diskriminasi. Adapun pentingnya pendidikan multikultural bagi peserta didik yaitu sebagai sarana alternatif pemecahan konflik, peserta didik diharapkan tidak 
Hermanto, Arita, Arifin. Implementasi Nilai Pendidikan Multikultural meninggalkan akar budayanya, dan pendidikan multikultural sangat relevan digunakan untuk demokrasi yang ada seperti sekarang ini.

Berdasarkan penjelasan tersebut di atas bahwa memang penting pendidikan multikultural dilakasanakan disekolah dasar agar peserta didik dapat memahami tentang keberagaman dan cara menghargai sebagai wujud nyata mencintai bangsa Indonesia yang majemuk ini. Selain dari pada itu para peserta didik sejak dini memahami perbedaan-perbedaan keragaman itu sebagai karunia Tuhan Yang Maha Esa yang patut di syukuri sehingga dalam implementasi nilai multikulturalisme dalam kehidupan sehari-hari dapat diinternalisasi dengan baik oleh peserta didik sekolah dasar baik di sekolah, keluarga, dan masyarakat.

Seperti yang dijelasakan dalam tujuan pendidikan multikultural dalam UU Sisdiknas ialah: menambahkan sikap simpati, respek, apresiasi dan empati terhadap penganut agama dan kultur yang berbeda.Tujuan utama dari pendidikan multikultural adalah untuk menanamkan sikap simpatik, respek, apresiasi, dan empati terhadap penganut agama dan budaya yang berbeda. Gorski dalam Budianta, (2003:13) pendidikan multikultural bertujuan untuk memfasilitasi pengalaman belajar yang memungkinkan peserta didik mencapai potensi maksimal sebagai pelajar dan sebagai pribadi yang aktif dan memiliki kepekaan sosial tinggi di tingkat lokal, nasional dan global serta mewujudkan sebuah bangsa yang kuat, maju, adil, makmur dan sejahtera tanpa perbedaan etnik, ras, agama dan budaya. Dengan semangat membangun kekuatan diseluruh sektor sehingga tercapai kemakmuran bersama, memiliki harga diri yang tinggi dan dihargai bangsa lain..

\section{SIMPULAN}

Berdasarkan hasil penelitian ini dapat disimpulkan bahwa implementasi nilainilai pendidikan multikultural dalam kehidupan di SD Negeri Sangiang Pulau Kabupaten Bima. Dilaksanakan secara terpadu melalui kegiatan intrakurikuler dan kegiatan eksatrakurikuler. Kegiatan yang sangat beragam, disesuaikan dengan minat dan bakat peserta didik. Hal itu dilakukan agar peserta didik dapat mempraktikan secara langsung sesuai dengan dunia nyata. Kegiatan intrakurikuler disekolah dapat dilakukan dengan penguatan materi tentang keberagaman yaitu tentang beragam suku, budaya, agama dan adat istiadat. Sementara dalam kegiatan ekstrakurikuler dapat dilakukan 
Hermanto, Arita, Arifin. Implementasi Nilai Pendidikan Multikultural dengan kegiatan kemah kebudyaan, karnaval pakaian adat istiadat tiap-tiap daerh yang ada di indonesia dan pendalaman mengenai bhineka tunggal ika dan pancasila. Dalam proses implementasi pendidikan multukultural tersebut juga tidak terlepas dari peran penting dari kepala sekolah, guru.

Oleh karena itu peran penting pendidikan multikultural dilakasanakan disekolah dasar agar peserta didik dapat memahami tentang keberagaman dan cara menghargai keberagaman tersebut sebagai wujud nyata mencintai bangsa Indonesia yang majemuk ini. Selain dari pada itu para peserta didik sejak dini diajarkan memahami perbedaanperbedaan keragaman itu sebagai karunia Tuhan Yang Maha Esa yang patut di syukuri sehingga dalam implementasi nilai multikulturalisme dalam kehidupan sehari-hari dapat diinternalisasi dengan baik oleh peserta didik sekolah dasar baik di sekolah, keluarga, dan masyarakat.

\section{UCAPAN TERIMA KASIH}

Rasa Syukur kepada Allah SWT, dan Terimakasih saya ucapkan kepada semua pihak yang sudah membantu dalam penyelesaian penelitian ini, terutama :

1. Kedua orang tua, kakak, dan semua keluarga yang selalu mendoakan, menyemangati dan mendukung penyelesaian penelitian ini.

2. Ibunda Prof. Dr. Ir. Arita Marini, M.E dan Bapak Dr. Arifin Maksum, M.Pd yang selalu membimbing dan mengarahkan peneliti untuk dapat menyelesaikan penelitian dan karya ilmiah ini.

3. Teman-teman dan semua pihak yang telah bekerja sama dan membantu kelancaran studi penelitian ini, terutama teman Pondokan Wahyu.

\section{DAFTAR RUJUKAN}

Anggito, A., \& Setiawan, J. (2018). Metodologi penelitian kualitatif. Sukabumi: CV Jejak (Jejak Publisher).

Baldah, Wardatul. Sumarna, Cecep dan Yuniarto, Bambang. 2016. Pengaruh Penanaman Nilai-nilai multikultural Terhadap Pembentukan Sikap Pluralis Siswa di MTS Negeri Babakan Ciwaringin Kabupaten Cirebon. Jurnal Edueksotis, 1 (1).

Budianta, M. (2003). "Multikulturalisme dan pendidikan multikultural: Sebuah Gambaran Umum”. Tsaqafah Vol 1, No. 2 P: 8-16 
Hermanto, Arita, Arifin. Implementasi Nilai Pendidikan Multikultural

Dike, Daniel. (2017). Pendidikan Multikultural Sekolah Dasar di Wilayah 3T. Jurnal DIDIKA: Wahana Ilmiah Pendidikan Dasar Vol 1, No. 2: 12-22.

Desmita. 2016. Pikologi Perkembangan Peerta Didik. Bandung: Remaja Rosda Karya.

Hanum, Farida dan Rahmadonna, Sisca. 2010. Implementasi Model Pembelajaran Multikultural SD di DIY. Jurnal Penelitian Ilmu Pendidikan, 3 (1): 89- 102.

Lincoln, P. Z. 2011. Educational Equality or Educational Equity. NUCB Journal of Economics And Information Science, 60 (1).

Milles, \& Huberman. (2013). Qualitative Data Analysis: A Methods Sourcebook. Los Angeles: SAGE Publications.

Moleong, L. (2017). Metodologi Penelitian Kualitatif. Bandung: PT Remaja Rosdakarya. Dipetik September 27, 2020.

Najmina, Nana. 2018. Pendidikan Multikultural dalam Membentuk Karakter Bangsa Indonesia. Jurnal Pendidikan Ilmu-Ilmu Sosial 10 (1): 52-56.

Praptini (2017). "Peranan Pendidikan Multikultural Dalam Menanamkan Pendidikan Nilai Untuk Membentuk Masyarakat Yang Menghargai Budaya Bangsa” Jurnal Unimed.

Sarona Gaharu (2014). "Peran Guru Dalam Menerapkan Pendidikan Multikultural (Studi Di SD Sanggar Anak Alam Bantul)”. Skripsi S1 Sosiologi Universitas Gadjah Mada.

Sudrajat. 2014. Pendidikan Multikultural Untuk Meningkatkan Kualitas Pembelajaran IPS di SD. JIPSINDO, 1 (1): 1-19.

Sugiyono. (2018). Metode Penelitian : Kuantitatif, Kualitatif, dan R\&D. Bandung: Alfabeta. Dipetik September 28, 2020

Undang-undang Republik Indonesia Nomor 20 Tahun 2003 tentang Sistem Pendidikan Nasional.

Wahyudin, Apri dan Elhefni. 2017. Strategi Pengembangan Pendidikan Multikultural di Indonesia. Jurnal Elementary, 3.

Wawancara Dengan Kepala Sekolah Melalui Via Telepon Seluler Pada Hari Kamis 29 Oktober 2020

wawancara dengan salah satu guru SD Negeri Sangiang Pulau melalui via telepon seluler pada hari kamis 30 oktober 2020

Yenny Puspita (2018), "Pentingnya Pendidikan Multikultural" Prosiding Seminar Nasional 21 Universitas Pgri Palembang 05 Mei 2018 Isbn 978-602-52451-0-7

Zamroni. 2011. Pendidikan Demokrasi pada Masyarakat Multikultural. Yogyakarta: Surya Sarana Grafika.

Zubaidi. 2004. "Telaah Konsep Multikulturalisme dan Implementasinya dalam Dunia Pendidikan”. Hermina Vol.3 no.1.p.77. 